\title{
Biochemical Profile and Productive Performance in Dairy Cows With Lameness During Postpartum Period
}

\author{
Renan Braga Paiano, ${ }^{1,2}$, Daniela Becker Birgel ${ }^{3}$, Rüdiger Daniel Ollhoff ${ }^{4}$ \& Eduardo Harry Birgel Junior ${ }^{1,3}$
}

\begin{abstract}
Background: Lameness in dairy cows is classified as a gait change caused by multifactorial process. The phase of the peripartum causes intense physiological changes for the adaptation of late gestation and onset of lactation. The aim of this study was to characterize the changes in the biochemical profile and productive performance in dairy cows with lameness during postpartum period.
\end{abstract}

Materials, Methods \& Results: This study was conducted at the University of São Paulo farm, in Pirassununga, São Paulo State, Brazil, from January to March 2017. A total, of 48 multiparous (2 to 3 lactations and 3-4 years old) dairy cows, that had the milk production of $9,200 \mathrm{~kg} /$ dairy cow in a period of 305 days in the previous lactation, were included in the study. All cows were managed under the same conditions and nutritional regimen. Evaluation of body condition score was performed by a single person on $-18,-12,-8,-5$, and -2 days before parturition, at parturition, and on days $1,7,14,21$, 30, 45 and 60 after parturition. Milk production was recorded on days 7, 14, 21, 30, 45 and 60 after parturition and saved in the software program. Blood samples were performed on $-18,-12,-8,-5$, and -2 days before parturition, at parturition, and on days 1, 7, 14, 21, 30, 45 and 60 after parturition. Blood samples were assayed for albumin, calcium, cholesterol, triglycerides, non-esterified fatty acids, $\beta$-hydroxybutyrate, urea, creatinine, gamma-glutamil-transferase and total protein concentrations. Dairy cows were divided into a lame group (11) and normal group (37) based on locomotion score from parturition to seven days postpartum. Lame cows was classified if their score was $>2$, and normal cows was classified if their score was $\leq 2$ and free of any disease. Dairy cows that suffer by any health disorder other than lameness were excluded from this study. Cow diagnosed with lameness outside the diagnostic period were excluded from this study. The averages of the milk production, body condition score and biochemical profile were compared with the Tukey's test. Lame cows showed lower $(P<0.05)$ concentrations of albumin (on days $-18-12,-8,-5,-2$ relative to parturition, at parturition, and on days $7,14,21,45$ and 60 after parturition) calcium (on days -18, -12, $-8,-5$ and -2 before parturition, and on days 7 , 14, 21, 45 and 60 after parturition), cholesterol (on days $-12,-8,-5$ before parturition and on days 7, 14, 21, 30, 45 and 60 after parturition) than normal cows. Cow with lameness showed higher $(P<0.05)$ concentration of triglyceride (on days $7,14,21,30,45$ and 60 after parturition), non-esterified fatty acids (on days 1, 7, 14, 21, 30, 45 and 60 after parturition) and -hydroxybutyrate (on days $-12,-5$ and -2 before parturition, at parturition, and on days 1, 14, 21 and 30 after parturition) than normal group. Cows with lameness presented higher $(P<0.05)$ values of body condition score on days -18 , -12 and -8 before parturition, and lower $(P<0.05)$ values on days $7,14,21,30,45$ and 60 after parturition than normal cows. Milk production was lower $(P<0.05)$ for cows with lameness (on days 7, 14, 21, 30, 45 and 60 after parturition) than normal cows.

Discussion: The overall prevalence of lameness in the evaluated period was $22.92 \%$ (11/48). Among lame cows, 7 presented laminitis, 2 had interdigital hyperplasia and 2 had sole ulcer. Our findings prove that the biochemical profile and productivity of dairy cows during the peripartum and postpartum period were affected by lameness at the early lactation.

Keywords: Holstein dairy cows, locomotor problem, peripartum, serum biochemistry.

DOI: $10.22456 / 1679-9216.93775$ (FMVZ), University of São Paulo (USP), São Paulo, SP, Brazil. ${ }^{2}$ Department of Veterinary Medicine, Faculty of Animal Science and Food Engineering (FZEA), USP, Pirassununga, SP, Brazil. ${ }^{3}$ Postgraduate Program in Animal Science, Catholic University of Paraná (PUC), Curitiba, PR, Brazil. CORRESPONDENCE: R.B. Paiano [renanpaiano@hotmail.com - Tel.: +55 (19) 3565-4200]. Department of Animal Reproduction, Faculty of Veterinary Medicine and Animal Sciences, USP. CEP 05508270 São Paulo, SP, Brazil. 


\section{INTRODUCTION}

Lameness is a change in gait caused by a multifactorial process, compromising animal health and welfare [40]. The prevalence of lameness in herds raised in freestall systems is $25 \%$ in the United States [14], and $37 \%$ and $48 \%$ in Europe [2,44]. Animals affected by this disorder present reduced production and fertility [8,24]. Lameness contributes to increased economic losses in the dairy industry, due to the costs of animal therapy, reduced production and disposal of milk due to the use of medicines $[9,19]$.

Peripartum is a challenging phase for the health of dairy cows; profound physiological changes occur during this period, including loss of body weight, reduction of dry matter intake, increase of serum cortisol concentration and reduction in the total number of leukocytes $[6,11,28,30,37]$. When these changes occur in a severe form, they may impair immune function and increase the risk of developing metritis, endometritis, metabolic and locomotor disorders $[5,11,42]$.

Due to the homeorrhetic changes that occur during the peripartum, the present study aimed to characterize the biochemical profile and the productive performance of lame Holstein dairy cows during the peripartum and postpartum period.

\section{MATERIALS AND METHODS}

Data

In total, 48 multiparous ( 2 to 3 lactations and 3-4 years old) Holstein dairy cows that had the average milk yield 9,200 $\mathrm{kg}$ in the previous lactation were included in the study. The cows were evaluated on the University of São Paulo farm, in Pirassununga, São Paulo State, Brazil, from January to March 2017. All cows were managed under the same conditions and nutritional regimen from 21 days prepartum until 60 days postpartum, as shown in Table 1 . The dry cows were kept on extensive grasslands, after parturition, cows were housed in free stalls barns. Cow were fed using a total mixed ration system twice a day, and milked twice a day. The footbath consisted of a $5 \%$ formalin solution applied at least twice a week, located at the exit of the milking parlor. All cows received a routine hoof trimming at least once per year at dry off.

Body condition score and milk yield

Animals were studied from the last 21 days prior to calving until 60 days postpartum. Body con- dition score (BCS) was evaluated by a single person using the 1 to 5-point scale by Ferguson et al. [15]. Milk production was recorded on each milking and saved in the software program (ALPROß) ${ }^{1}$.

Table 1. Diet composition - nutritional regimen from 21 days prepartum until 60 days postpartum.

\begin{tabular}{lc}
\hline Item & Prepartum - Postpartum \\
\hline Ingredients, \% of DM & 58.71 \\
Corn silage & 27.63 \\
Corn, ground & 8.09 \\
Soybean meal & 0.92 \\
Urea & 4.65 \\
Mineral and vitamin mix ${ }^{1}$ & - \\
Mineral and vitamin mix ${ }^{2}$ & - \\
Limestone & - \\
Salt & 46.71 \\
Nutrient composition, DM basis & 14.71 \\
Dry matter, \% & 42.36 \\
CP, \% & 3.03 \\
NDF, $\%$ & -99.18 \\
Ether extract, \% & \\
DCAD, mEq/kg MS & \\
\hline DM: dry matter; CP: crude protein; NDF: neutral detergent fiber; DCAD: \\
dietary cation-anion difference. ${ }^{1}$ Contained per kilogram: Na 2.4g, Ca \\
22.8g, P 2.2g, Mg 0.9 g, S 4.8 g; Co 1.4 mg, Cu 45.4 mg; Mn 135 mg; \\
I2.7 mg, Se 1.4, Zn 181.4 mg, Vitamin A, 18.000 UI, Vitamin D, 1.800 \\
UI, Vitamina E, 65.3 mg, monensin 50 mg. ${ }^{2}$ Contained per kilogram: Na \\
9.3g, Ca 16.6g, P 2.3g, Mg 1.2 g, S 4,8 g, Co 1.8 mg, Cu 60.5 mg, Mn \\
179.9 mg, I 3.6 mg, Se 1.8, Zn 241.9 mg, Vitamin A, 24.000 UI; Vitamin \\
D, 2.400 UI, Vitamin E, 87 mg, monensin 66 mg. ${ }^{3}$ DCAD, dietary cation- \\
anion difference, calculated as follows: DCAD = (mEq of Na + mEq of \\
K) - (mEq of S + mEq of Cl).
\end{tabular}

\section{Collection of blood samples}

Blood samples were performed on 13 samples at the following time points: $18,12,8,5$, and 2 days before calving, parturition, 1, 7, 14, 21, 30, 45 and 60 days postpartum. Blood samples were collected from the coccygeal vein into test tubes without anticoagulant and were centrifuged at $2000 \times g$ for 15 min within 2 $\mathrm{h}$ of collection. Serum samples were stored at $-20^{\circ} \mathrm{C}$ until analysis.

\section{Measurement of biochemical profile}

Analyses were conducted at the Multiuser Laboratory in Clinical Veterinary Analysis at the University of São Paulo. Serum albumin, calcium, cholesterol, triglycerides, non-esterified fatty acids (NEFA), $\beta$-hydroxybutyrate (BHB), urea, creatinine, total protein and gamma-glutamil-transferase (GGT) analyses were performed using commercial kits in an automatic biochemistry system (Randox Rx Daytona Chemistry) ${ }^{2}$. 


\section{Diagnosis of lameness}

The visual locomotion score was evaluated from 21 days prepartum until 60 days postpartum for each cow by the same operator using a 1 to 5 scale [35], where 1 = normal, 2 = mildly lame, 3 = moderately lame, 4 = lame and 5 = severely lame. Cows were considered clinically lame if their score was $>2$ evaluated from parturition to 7 days postpartum, and cows with a score $\leq 2$ and free of any disease were classified as normal. Cows that were concurrently affected by any health disorder other than lameness at the time of enrolment were excluded from the study, as well as cows classified with lameness outside the diagnostic period for locomotor disorders. Treatment of lame cows was performed by veterinarians in the research team.

\section{Statistical analysis}

The SAS (package version 9.3) 3 $^{3}$ was used for milk production, BCS and biochemical data analysis using GLIMMIX procedures. After testing for normal distributions of the data, Tukey's test was used to investigate differences between means at $P<0.05$.

\section{RESULTS}

The overall prevalence of lameness in the evaluated period was $22.92 \%$ (11/48). Among lame cows, 7 presented laminitis, 2 had interdigital hyperplasia and 2 had sole ulcer. According to the locomotion score, three cows had a score of 3 , four presented a score of 4 and four cows had a score of 5 .

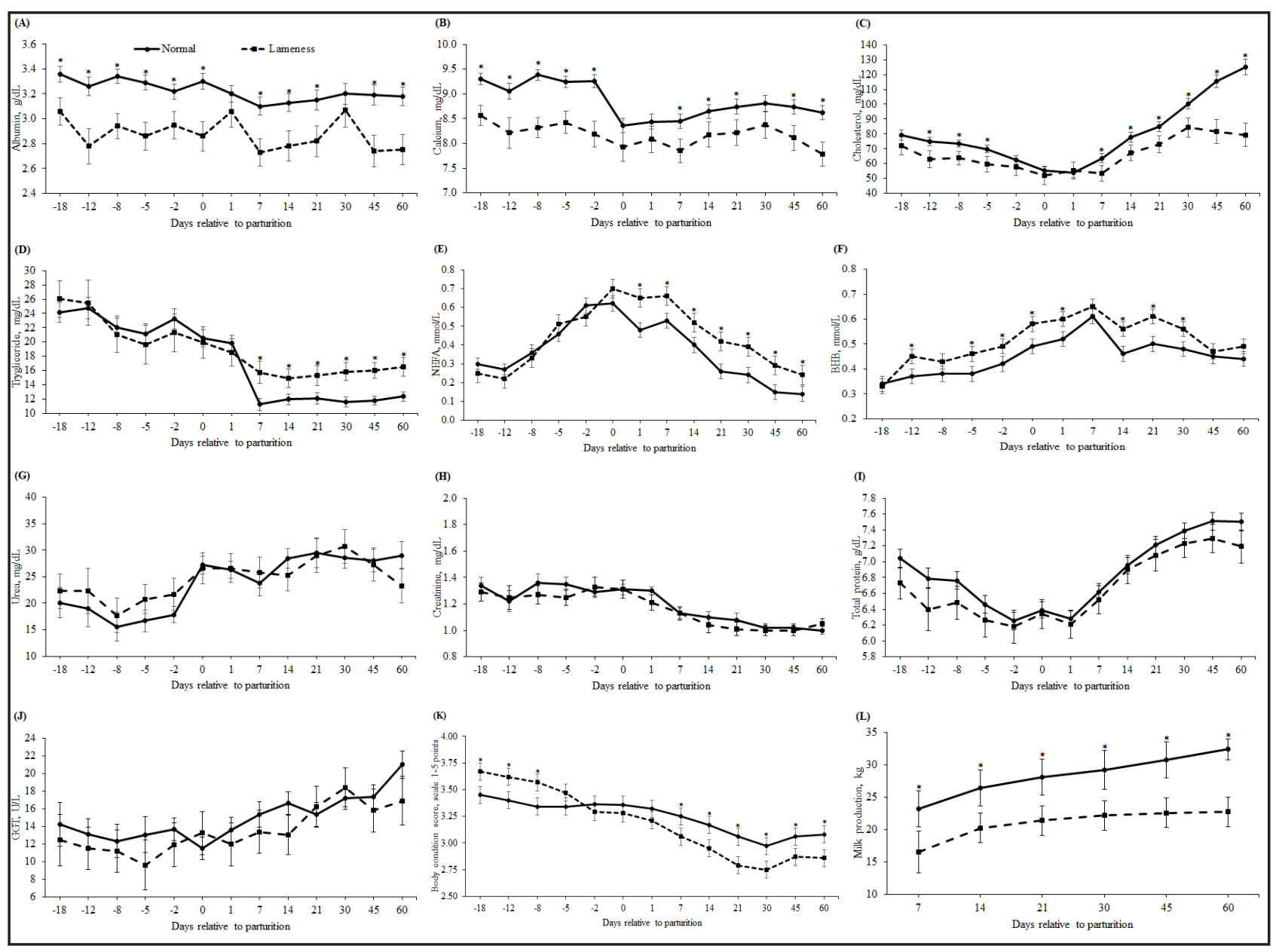

Figure 1. Biochemical profile, BCS and milk production. A- Serum albumin; B- calcium; C- cholesterol; D- trygliceride; E- NEFA; F- BHB; G- urea; $\mathrm{H}$ - creatinine; I- total protein concentration; J- GGT; K- body condition score and milk production; L- evaluation (least squares means \pm SEM) in relation to days to parturition in lame cows and nonlame cows. ${ }^{*}$ Specifies significant effects at $P<0.05$. 
Figure 1 shows the results of the biochemical profile, BCS and milk production. Lower concentrations of albumin were observed in lame cows during prepartum and postpartum. Lame cows showed lower concentrations of albumin in the following periods: -18 $-12,-8,-5,-2$ days relative to parturition, at parturition, and on days $7,14,21,45$ and 60 after parturition than normal cows $(P<0.05)$. Calcium concentrations were lower in lame cows on $-18,-12,-8,-5,-2,7,14,21,45$ and 60 days with respect to parturition when compared to normal group $(P<0.05)$. Cholesterol concentrations were lower $(P<0.05)$ on days $-12,-8,-5$ before parturition and on days $7,14,21,30,45$ and 60 after parturition for lame group compared to normal cows. The lame group presented higher triglyceride concentrations than normal cows at 7, 14, 21, 30, 45 and 60 days after parturition $(P<0.05)$. Lame cows showed higher concentrations of NEFA on days $1,7,14,21$, 30,45 and 60 after parturition than normal cows $(P<$ $0.05)$. BHB concentrations were higher $(P<0.05)$ on days $-12,-5$ and -2 before parturition, at parturition, and on days 1, 14, 21 and 30 after parturition for lame group compared to normal cows. No difference was noted among the groups evaluated for urea, creatinine, total protein and GGT concentrations. According to the BCS, lame cows showed higher values on days $-18,-12$ and -8 before parturition, and lower values on days 7 , 14, 21, 30, 45 and 60 after parturition when compared to normal cows $(P<0.05)$. Milk production was lower $(P<0.05)$ for lame cows on days $7,14,21,30,45$ and 60 after parturition compared to normal cows .

\section{DISCUSSION}

In the peripartum period, due to nutrient partitioning for milk production, dairy cows may go through a period of negative energy balance (NEB) to meet energy demands [3]. To overcome this energy deficit, there is an increase in NEFA mobilization. When the negative energy balance is exaggerated, it is possible to identify this change by elevated NEFA serum concentrations in the bloodstream and by increased production and circulation of ketone bodies, such as BHB [28]. Our results indicate an intense NEB in lame cows due to the increased concentration of NEFA and BHB.

The values for triglyceride concentrations in lame cows at 7, 14, 21, 30, 45 and 60 days postpartum were higher than the limits recommended for the species [23]. The formation of triglycerides occurs after the esterification of NEFA in the hepatic tissue; the triglycerides are sent to the tissues, including the mammary gland, contributing to the formation of fat in the milk [12,26].

Dairy cows with a high BCS at the beginning of the transitional period may present a high loss of BCS during the postpartum period, which may cause impaired immune function and an intense proinflammatory state; these factors increase the risk of the cow developing diseases during the postpartum period $[25,32,33,36]$. Our results evidenced that the lame cows had the BCS at the beginning of the transition period (3.7) above than the recommended (3.25) [36].

In addition, lame cows lost $>0.5$ points during the first month of lactation. The loss of BCS above 0.25 points during the first month of lactation may affect the health of dairy cows [33]. Association between locomotor problems and low body condition scores during the peripartum period was demonstrated, with this finding being mainly related to the reduction of adipose tissue in the digital cushion [6].

Positive association between BCS and the digital cushion thickness was reported [6], supporting the hypothesis that low BCS is a risk factor for lameness. Animals that present severe loss of body condition scores feature intense mobilization of fat, raising the risk of lameness [7,20,31].

The values observed on lame cows for albumin concentrations at $-18,-12,-8,-5,-2,0,7,14,21,45$ and 60 days relative to parturition were below those recommended as normal [23]. Cows with albumin concentrations $<3.25 \mathrm{~g} / \mathrm{dL}$ at prepartum are more likely to develop disease postpartum [41]. Hypoalbuminemia can occur due to decreased food intake, protein deficiency, and decreased liver synthesis among other factors [17]. However, based on the values for total protein, urea concentrations, creatinine and GGT exclude these possibilities. Albumin is an acute phase negative protein and its reduction is indicative of a proinflammatory state, even before the onset of disease [5]. In the present study, the evaluation of albumin during prepartum suggests its performance as an early marker of inflammatory process, with the reduced values of albumin related to an inflammation at the moment that was expressed as lameness in the cows.

The calcium concentration in lame cows at 7 and 60 days after parturition was lower than that described as normal [16]. During parturition until 7 
days after parturition $82 \%(9 / 11)$ of the lame cows had serum calcium concentration $<8.0 \mathrm{mg} / \mathrm{dL}$, whereas in normal cows, this value was $27 \%$ (10/37). About $45 \%$ of calcium is complexed to albumin [17]. The decrease in calcium concentration may occur due to a reduction in serum albumin concentration [34]. Casagrande [10] found that cows with low concentration of calcium in the first 10 days after parturition present slower the rate of hoof growth when compared with the month prior to the calving, with about $35 \%$ lower for the dorsal wall and $24 \%$ for abaxial wall. Calcium participates in the keratinization process of the hoof, activating the epidermal transglutaminase enzyme that contributes to the fiber connections of cellular keratin [27]. Moreover, low serum calcium levels in cows with locomotor problems was related [4]. In this sense, the low concentration of calcium can interfere in the formation of fragile hooves.

Cholesterol is a component of lipoproteins, forms the lipid composition of cell membranes, helps liver functionality, and is considered a negative acutephase protein [38]. Cows that present low cholesterol concentrations are more likely to develop metritis, retained placenta and mastitis [22]. The lower values of cholesterol concentration during prepartum in the lame cows indicate that prepartum cholesterol assessment may be an important marker of postpartum cow health status. It has been demonstrated that lame cows present reduced eating times, and less frequent visits to the concentration feeder than normal cows [43]. In addition, it was shown a reduction in food intake and feed frequency in lame cows compared to normal cows [39]. The lower cholesterol concentrations in lame cows can be explained by lower food intake, which is caused by lameness [18,21].

According to the milk production, as expected, the lame cows presented low milk production, which is associated with pain and stress caused by painful hoof lesions, in addition to the lower dry matter intake $[1,13,44]$.

In the state of São Paulo, the wettest period of the year is concentrated during the summer, the excess of rain during this phase of the year increased soil moisture and clay formation, which in conjunction with organic matter, favored the fragility of the hooves of cows, it is important to note that during prepartum period, no cow presented lameness. The stress of parturition associated with environmental change may have contributed to the high number of lame cows during early puerperium.

\section{CONCLUSIONS}

Our findings show that lameness at the beginning of the lactation had negative effects on the biochemical profile of dairy cows. In addition, according to our data, cows with lameness show impaired productivity during the postpartum period.

\section{MANUFACTURERS \\ ${ }^{1}$ DeLaval. Kansas City, MO, USA. \\ ${ }^{2}$ BioAgilytix Labs. Durham, NC, USA. \\ ${ }^{3} \mathrm{SAS} \circledast$ Institute. Cary, NC, USA.}

Acknowledgements. The authors would like to thank the employees of the University of São Paulo for their involvement in this study. This study was financed in part by the Coordenação de Aperfeiçoamento de Pessoal de Nível Superior - Brasil (CAPES) - Finance Code 001.

Ethical approval. All animal procedures were approved by the Bioethics Committee of the School of Veterinary Medicine and Animal Sciences, University of São Paulo, São Paulo, Brazil (approval number: 8022150216/2018).

Declaration of interest. The authors report no conflicts of interest. The authors alone are responsible for the content and writing of the paper.

\section{REFERENCES}

1 Bach A., Dinarés, M., Devant M. \& Carré X. 2007. Associations between lameness and production, feeding and milking attendance of Holstein cows milked with an automatic milking system. Journal of Dairy Research. 74: 40-46.

2 Barker Z.E., Leach K.A., Whay H.R., Bell N.J. \& Main D.C.J. 2010. Assessment of lameness prevalence and associated risk factors in dairy herds in England and Wales. Journal of Dairy Science. 93: 932-941.

3 Barletta R.V., Maturana Filho M., Carvalho P.D., Del Valle T.A., Netto A.S., Rennó F.P., Mingoti R.D., Gandra J.R., Mourão G.B., Fricke P.M., Sartori R., Madureira E.H. \& Wiltbank M.C. 2017. Association of changes among body condition score during the transition period with NEFA and BHBA concentrations, milk production, fertility, and health of Holstein cows. Theriogenology. 104: 30-36.

4 Belge F., Bildik A., Belge A., Kiliçalp D. \& Atasoy N. 2004. Possible association between chronic laminitis and some biochemical parameters in dairy cattle. Australian Veterinary Journal. 82: 556-557. 
5 Bertoni G., Minuti A. \& Trevisi E. 2015. Immune system, inflammation and nutrition in dairy cattle. Animal Production Science. 55: 943-948.

6 Bicalho R.C., Machado V.S. \& Caixeta L.S. 2009. Lameness in dairy cattle: a debilitating disease or a disease of debilitated cattle? A cross- sectional study of lameness prevalence and thickness of the digital cushion. Journal of Dairy Science. 92: 3175-3184.

7 Bicalho R.C. \& Oikonomou G. 2013. Control and prevention of lameness associated with claw lesions in dairy cows. Livestock Science. 156: 96-105.

8 Bicalho R.C., Warnick L.D. \& Guard C.L. 2008. Strategies to analyze milk losses caused by diseases with potential incidence throughout the lactation: a lameness example. Journal of Dairy Science. 91: 2653-2661.

9 Bruijnis M.R., Hogeveen H. \& Stassen E.N. 2010. Assessing economic consequences of foot disorders in dairy cattle using a dynamic stochastic simulation model. Journal of Dairy Science. 93: 2419-2432.

10 Casagrande F.P. 2013. Perfíl metabólico e mineral de vacas no período peri-parto: qualidade e conformação dos cascos. 125f. Belo Horizonte, MG. (Doutorado em Ciências), Universidade Federal de Minas Gerais.

11 Contreras G.A. \& Sordillo L.M. 2011. Lipid mobilization and inflammatory responses during the transition period of dairy cows. Comparative Immunology, Microbiology \& Infectious Diseases. 34: 281-289.

12 Drackley J.K. 1999. Biology of dairy cows during the transition period: The final frontier. Journal of Dairy Science. 82: 2259-2273.

13 Dyer R.M., Neerchal N.K., Tasch U., Wu Y., Dyer P. \& Rajkondawar P.G. 2007. Objective determination of claw pain and its relationship to limb locomotion score in dairy cattle. Journal of Dairy Science. 90: 4592-4602.

14 Espejo L.A. \& Endres M.I. 2007. Herd-level risk factors for lameness in high-producing Holstein cows housed in freestall barns. Journal of Dairy Science. 90: 306-314.

15 Ferguson J.D., Galligan D.T. \& Thomsen N. 1994. Principal descriptors of body condition score in Holstein cows. Journal of Dairy Science. 77: 2695-2703.

16 Goff J.P. 2008. The monitoring, prevention, and treatment of milk fever and subclinical hypocalcemia in dairy cows. The Veterinary Journal. 176: 50-57.

17 González F.H.D. 2000. Use of metabolic profile for determining the nutritional status of beef cattle. In: González F.H.D., Barcellos O.J., Ospina H. \& Ribeiro L.A.O. (Eds). Metabolic profile in ruminants: their use in nutrition and nutritional diseases. Porto Alegre: Editora UFRGS, pp.77-88.

18 Guretzky J.N.A, Carlson D.B., Garrett J.E. \& Drackley J.K. 2006. Lipid metabolite profiles and milk production for Holstein and Jersey cows fed rumen-protected choline during the periparturient period. Journal of Dairy Science. 89: 188-200.

19 Hernandez J., Shearer J.K. \& Webb D.W. 2001. Effect of lameness on the calving-to-conception interval in dairy cows. Journal of the American Veterinary Medical Association. 218: 1611-1614.

20 Hoedemaker M., Prange D. \& Gundelach Y. 2009. Body condition change ante- and postpartum, health and reproductive performance in German Holstein cows. Reproduction in Domestic Animals. 44: 167-173.

21 Huzzey J.M., Nydam D.V., Grant R.J. \& Overton T.R. 2011. Associations of prepartum plasma cortisol, haptoglobin, fecal cortisol metabolites, and nonesterified fatty acids with postpartum health status in Holstein dairy cows. Journal of Dairy Science. 94: 5878-5889.

22 Kaneene J.B., Miler R.A., Herdt T.H. \& Gardiner J.C. 1997. The association of serum nonesterified fatty acids and cholesterol, management and feeding practices with peripartum disease in dairy cows. Preventive Veterinary Medicine. 31: 59-72.

23 Kaneko J.J., Harvey J.W. \& Bruss M. 2008. Clinical biochemistry of domestic animals, 6th edn. San Diego: Academic Press, 928p.

24 Leach K.A., Tisdall D.A., Bell N.J., Main D.C.J. \& Green L.E. 2012. The effects of early treatment for hindlimb lameness in dairy cows on four commercial UK farms. The Veterinary Journal. 193: 626-632.

25 Leblanc S. 2010. Monitoring metabolic health of dairy cattle in the transition period. Journal of Reproduction and Development. 56: S29-35.

26 McManaman J.L. 2015. Lipid Transport in the Lactating Mammary Gland. Journal of Mammary Gland Biology and Neoplasia. 19: 35-42.

27 Mülling C., Bragulla H., Reese S., Budras K.D. \& Steinberg W. 1999. How structures in bovine hoof epidermis are influenced by nutritional factors. Anatomia, Histologia, Embryologia. 28: 103-108. 
28 Ospina P.A., Nydam D.V., Stokol T. \& Overton T.R. 2010. Associations of elevated nonesterified fatty acids and bhydroxybutyrate concentrations with early lactation reproductive performance and milk production in transition dairy cattle in the northeastern United States. Journal of Dairy Science. 93: 1596-603.

29 Paiano R.B., Birgel D.B. \& Birgel Junior E.H. 2019. Uterine Involution and Reproductive Performance in Dairy Cows with Metabolic Diseases. Animals. 9: 93.

30 Paiano R.B., Lahr F.C., Poit D.A.S., Costa A.G.B.V.B., Birgel D.B. \& Birgel Junior E.H. 2018. Biochemical profile in dairy cows with artificial induction of lactation. Pesquisa Veterinária Brasileira. 38: 2289-2292.

31 Randall L.V., Green M.J., Chagunda M.G.G., Mason C., Archer S.C., Green L.E. \& Huxley J.N. 2015. Low body condition predisposes cattle to lameness: An 8-year study of one dairy herd. Journal of Dairy Science. 98: 3766-3777.

32 Roche J.R., Dillon P.G., Stockdale C.R., Baumgard L.H. \& VanBaale M.J. 2004. Relationships among international body condition scoring systems. Journal of Dairy Science. 87: 3076-3079.

33 Roche J.R., Friggens N.C., Kay J.K., Fisher M.W., Stafford K.J. \& Berry D.P. 2009. Body condition score and its association with dairy cow productivity, health, and welfare. Journal of Dairy Science. 92: 5769-5801.

34 Seifi H.A., Mohri M., Ehsani A., Hosseini E. \& Chamsaz M. 2005. Interpretation of bovine serum total calcium: effects of adjustment for albumin and total protein. Comparative Clinical Pathology. 14: 155-159.

35 Sprecher D., Hostetler J.D.E. \& Kaneene J.B. 1997. A lameness scoring system that uses posture and gait to predict dairy cattle reproductive performance. Theriogenology. 47: 1179-1187.

36 Stefańska B., Poźniak A. \& Nowak W. 2016. Relationship between the pre- and postpartum body condition scores and periparturient indices and fertility in high-yielding dairy cows. Journal of Veterinary Research. 60: 81-90.

37 Tarlton J.F., Holah D.E., Evans K.M., Jones S., Pearson G.R. \& Webster A.J.F. 2002. Biomechanical and histopathological changes in the support structures of bovine hooves around the time of first calving. The Veterinary Journal. 163: 196-204.

38 Trevisi E., Jahan N., Bertoni G., Ferrari A. \& Minuti A. 2015. Pro-inflammatory cytokine profile in dairy cows: consequences for new lactation. Italian Journal of Animal Science. 14: 285-292.

39 Thorup V.M., Nielsen B.L., Robert P.E., Giger-Reverdin S., Konka J., Michie C. \& Friggens N.C. 2016. Lameness affects cow feeding but not rumination behavior as characterized from sensor data. Frontiers in Veterinary Science. 3 : 37.

40 Van de Gucht T., Saeys W., Van Meensel J., Van Nuffel A., Vangeyte J. \& Lauwers L. 2018. Farm-specific economic value of automatic lameness detection systems in dairy cattle: From concepts to operational simulations. Journal of Dairy Science. 101: 637-648.

41 Van Saun R.J. 2004. Metabolic profiling and health risk in transition cows. In: Proceedings of the 37th Annual American Association of Bovine Practitioners Convention (Ft. Worth, USA). pp.212-213.

42 Van Saun R.J. 2016. Indicators of dairy cow transition risks: Metabolic profiling revisited. Tierarztliche Praxis Ausgabe G: Grosstiere - Nutztiere. 44: 118-126.

43 Weigele H.C., Gygax L., Steiner A., Wechsler B. \& Burla J.B. 2018. Moderate lameness leads to marked behavioral changes in dairy cows. Journal of Dairy Science. 101: 2370-2382.

44 Whay H.R., Main D.C.J., Green L.E. \& Webster A.J.F. 2003. Assessment of the welfare of dairy cattle using animalbased measurements: Direct observations and investigation of farm records. Veterinary Record. 153: 197-202. 